\title{
Pengembangan instrumen penilaian kinerja peserta didik berbasis pendekatan saintifik pada praktikum pengukuran kelas X SMA
}

\author{
Vina Serevina ${ }^{1}$, MM, Aris Santoso ${ }^{2}$, Cecep Rahmat ${ }^{3}$ \\ Pascasarjana Pendidikan Fisika, FMIPA Universitas Negeri Jakarta \\ Jl. Rawamangun Muka No.I, Jakarta Timur I3220 \\ Surat-e: vina.serevina77@gmail.com ${ }^{1}$,arrasy99@gmail.com², gorbacheefs@gmail.com
}

Penelitian ini bertujuan untuk mengembangkan instrumen penilaian kinerja berbasis pendekatan saintifik pada materi pengukuran kelas X SMA untuk mengukur kinerja yang valid dan reliabel. Penelitian ini menggunakan penelitian pengembangan Borg dan Gall. Penelitian ini dilakukan di Universitas Negeri Jakarta pada bulan Agustus - November 2017. Tahap uji coba ke peserta didik dilakukan di Kelas X SMAN 73 Jakarta. Penelitian ini menggunakan adalah jenis research and development, studi pengembangan yang dilakukan mengadopsi siklus Borg dan Gall, dengan tahapan studi literature (Research and information collecting), perencanaan (Planning), Pengembangan produk awal (Develop preliminary form of product), Uji coba lapangan skala terbatas (Preliminary field testing), revisi produk (Main product revision), Uji Coba Skala utama (Main field testing), Penyempurnaan hasil uji coba skala utama (Operational product revision). Uji validasi produk (Operational field testing), melakukan revisi akhir (Final product revision) dan Penyebarluasan produk yang dikembangkan (Dissemination and implementation). Instrumen diujikan secara terbatas pada peserta didik kelas X SMA N 73 Jakarta, hasil uji validitas butir dari 57 butir menjadi 48 butir yang valid. Uji Reliabilitas menggunakan Alpha Crobach. Hasil $r$ hitung 0,864 dimana $\mathrm{r}$ tabel 0,334, berdasarkan hasil penelitian instrumen penilaian kinerja berbasis saintifik dapat mengukur kinerja pada kegiatan pembelajaran fisika materi pengukuran.

This study aims to develop student performance appraisal instruments based on the scientific approach of student performance on high school physics measurement material for a valid and reliable result. This study uses research and development of Borg and Gall. It was conducted at the Jakarta State University in August - November 2017. In the testing phase to the students conducted in X Class of 73 Jakarta Senior High School. It uses the type of research and development, the development studies were conducted using the Borg and Gall cycles, with phase of literature study research and information collecting, planning, develop preliminary form of product, preliminary field testing, main product revision, main field testing, operational product revision, operational field testing, final product revision and dissemination and implementation. The instrument is tested on a limited basis for students of grade X of 73 Jakarta Senior High School, the results of the analysis of the instrument that has been tested its validity have decreased the number of grains from 57 to 48 items valid. While the reliability test using Alpha Cronbach. From the calculation obtained $r$ count 0,864 with $r$ table 0,334, from the results of this study can be concluded that the instruments based on scientific performance appraisal meet the requirements and feasible to be used as an instrument of performance appraisal on the learning activity of physics measurement material.

Kata kunci: performance appraisal instrument, scientific approach, borg and gall development model 
Pengembangan Instrumen penilaian kinerja peserta didik berbasis pendekatan saintifik pada praktikum pengukuran kelas X SMA

\section{Pendahuluan}

Proses belajar dan mengajar, memiliki aspek-aspek yang harus dievaluasi. Instrumen sebagai alat penilaian penting untuk dikembangkan dalam poses penilaian dalam pembelajaran. Berbagai studi di sekolah menyatakan pengetahuan mempersiapkan instrument penilaian masih kurang dan guru sering membuat instrumen tanpa mengikuti prinsip-prinsip tertentu. Namun dilain pihak penilaian hasil belajar harus dilakukan seakurat mungkin menggunakan instrumen penilaian yang tepat.

Penilaian tidak hanya dilakukan pada ranah kognitif saja, tapi secara keseluruhan, penilaian menjadi bagian dari pembangunan sikap, pengetahuan dan keterampilan yang dilakukan dalam cara yang nyata dan komperhensif berdasarkan kegiatan peserta didik. Prinsip umum dan penting dalam proses penilaian atau evaluasi, yaitu ada hubungan komponen pembelajaran antara lain, tujuan pembelajaran, kegiatan pembelajaran, dan evaluasi. kegiatan evaluasi sangat tergantung pada instrumen yang digunakan dalam proses evaluasi [I]. Untuk menghasilkan instrumen yang berkualitas dalam proses pembelajaran terdapat beberapa tahapan yang perlu dilakukan, di antaranya: (a) menelaah kurikulum dan buku pelajaran, (b) merumuskan tujuan instruksional khusus terkait materi yang akan dipelajari, (c) membuat kisi-kisi instrumen penilaian, (d) menyusun butir instrumen berdasarkan kisi-kisi instrumen yang telah dibuat, (e) membuat dan menentukan kunci jawaban soal [2]. Penialain hasil belajar meliputi sikap kompetensi, pengetahuan dan keterampilan yang dilakukan secara seimbang untuk menentukan posisi relative pelajar pada standar yang telah diterapkan. Oleh karena itu sistem evaluasi belajar mulai tumbuh dari sistem tradisional menjadi sistem penilaian yang lebih otentik (nyata), dan salah satu bagian dari penilaian otentik menilai keterampilan peserta didik (psikomotor) selama proses pembelajaran.

Penilain autentik terdiri dari penilaian kelas, proyek atau portofolio menggunakan ukuran atau rubrik tertentu [3]. Perkembangan orientasi pendidikan, tidak hanya aspek pengetahuan namun juga keterampilan, menuntut pendidik untuk melaksanakan penilaian unjuk kerja [4].

Penilaian kinerja umumnya dihargai untuk pengujian pengetahuan dan pemahaman peserta didik yang mendalam mengenai konsep dan strategi penyelidikan untuk membuat peserta didik terlihat berpikir, dan unruk mengukur keterampilan dalam berkomunikasi tentang ilmu pengetahuan mereka [5]. Penilaian kinerja adalah bagian dari penilaian autentik yang dianggap mampu mengukur hasil keseluruhan belajar, sehingga peserta didik lebih baik karena penilaian ini mengevaluasi kemajuan belajar yang tidak hanya melalui hasil tetapi juga proses dan dalam berbagai cara. Kinerja penilaian merupakan teknik penilaian sangat dianjurkan dalam fisika belajar terutama untuk psikomotor. Penilaian kinerja dapat juga digunakan sebagai penilaian alternatif. Jadi penilaian kinerja dapat membantu untuk mengetahui tingkat pengetahuan peserta didik.

Studi tentang penilaian kinerja yang dilakukan oleh [6] Universitas Marmara pada tahun 2008 di jurnal pendidikan sains turki menunjukkan bahwa penilaian kinerja ini menyediakan bantuan bagi peserta didik untuk membangun dan mengembangkan pengetahuan mereka, dimana mengajar dan penilaian adalah dua proses yang memberi makna satu sama lain. Oleh karena itu, penilaian kinerja sangat diperlukan sebagai perantara yang mampu memberikan umpan balik kepada peserta didik dalam proses belajar. Selain itu, penilaian kinerja juga dianggap sangat penting dalam membantu guru untuk membangun pengetahuan peserta didik.

Penilaian kinerja yang ada masih menciptakan berbagai kendala dan kekurangan dalam pelaksanaan dan tidak dapat membantu guru dalam melaksanakan penilaian. Kurangnya penilaian kinerja adalah subjektivitas dan inkonsistensi skor hasil. Kendala lain adalah bimbingan mencetak di instrumen menjadi tidak jelas, sementara komponen yang dianggap sulit untuk diamati, umumnya hanya satu orang adalah bidang studi, guru yang dinilai komponen dan jumlah peserta didik dinilai cukup banyak, mungkin ada kecenderungan untuk rata rata tinggi atau sebaliknya. Untuk itu penilaian kinerja perlu dikembangkan lebih lanjut untuk mengatasi atau meminimalkan kendala sebagaimana yang disebutkan di atas [7]. Keberhasilan kegiatan evaluasi belajar sangat bergantung pada instrumen tes yang digunakan. Instrumen tes memiliki peran penting dalam mengukur hasil belajar peserta didik. Sehingga diperlukan instrumen tes yang baku.

Menurut [8] fitur penilaian pendidikan teridi atas Traditional assessment freatures dan Performance assessment freatures. Penilaian kinerja telah muncul sebagai metode alternatif untuk mengukur apa yang peserta didik ketahui dan dapat Ia lakukan secara nyata. Penilaian kinerja merupakan bagian dari penilaian autentik yang dianggap mampu untuk lebih mengukur secara keseluruhan hasil belajar peserta didik, karena penilaian ini menilai kemajuan belajar bukan melalui hasil tetapi juga proses dan dengan berbagai cara. Penilaian kinerja menjadi salah satu teknik penilaian yang sangat disarankan dalam pembelajaran fisika khususnya untuk ranah psikomotorik. Penilaian kinerja juga dapat diartikan sebagai situasi yang terstruktur dimana informasi yang dibutuhkan diberikan kepada seseorang untuk menghasilkan respon yang dapat dinilai [9]. Bentuk penilaian kinerja ini dapat membantu perkembangan pengetahuan peserta didik.

Penelitian mengenai Performance Assessment yang dilakukan oleh [6] pada tahun 2008 dalam Journal of 
Pengembangan Instrumen penilaian kinerja peserta didik berbasis pendekatan saintifik pada praktikum pengukuran kelas X SMA

Turkish Science Education, menunjukkan bahwa Performance Assessment memberikan bantuan kepada peserta didik untuk membangun dan mengembangkan pengetahuannya, dimana pengajaran dan penilaian merupakan dua proses yang saling memberikan makna satu sama lain. Oleh karena itu, Performance Assessment sangat diperlukan sebagai sebuah perantara yang mampu memberikan timbal balik kepada peserta didik dalam proses pembelajaran. Di samping itu, Performance Assessment ini juga sangat dibutuhkan dalam membantu guru untuk membangun pengetahuan peserta didik hal tersebut senada dengan [IO] merekomendasikan agar menggunakan asesmen kinerja untuk mengukur kompetensi praktikum dengan menggunakan rubrik asesmen dengan kriteria indikator asesmen yang jelas dan dapat dilakukan oleh peserta didik

Penelitian yang dilakukan oleh Arum Nurul Hidayah pada tahun 2013 [II] tentang pengembangan penilaian unjuk kerja berbasis pendekatan inkuiri untuk peserta didik SMP topik suhu dan pemuaian, menunjukkan bahwa penilaian kinerja dapat menjadi sebuah pembaharuan dalam bentuk penilaian yang dilakukan oleh dosen, penilaian kinerja juga dapat membantu peserta didik untuk mengkonstruksikan pengetahuan melalui keterampilan yang dimilikinya dan juga dapat memberikan informasi secara keseluruhan terkait perkembangan dan pencapaian belajar peserta didik. Namun, penilaian kinerja yang ada masih memiliki keterbatasan dalam pelaksanaannya.

Penilaian kinerja yang sudah ada masih menimbulkan berbagai kendala dan kekurangan dalam pelaksanaannya dan belum bisa membantu tugas guru dalam melaksanakan penilaian. Salah satu kekurangan penilaian kinerja adalah subjektivitas dan inkonsistensi dari penilai dalam memberi skor. Kendala lainnya adalah pedoman penskoran dalam instrumen tidak jelas, komponen yang dinilai sulit untuk diamati, penilai (rater) umumnya hanya satu orang yaitu dosen bidang studi, sedangkan kompenen-kompenen yang dinilai dan jumlah peserta didik yang dinilai cukup banyak, kemungkinan ada kecendrungan untuk memberi nilai tinggi atau sebaliknya. Untuk itu penilaian kinerja yang ada perlu dikembangkan lebih lanjut untuk mengatasi atau meminimalisasi kendala-kendala seperti yang disebutkan diatas.

Dari hasil survei tentang analisis kebutuhan instrumen penilaian kinerja peserta didik pada materi pengukuran yang telah di isi oleh 30 guru fisika SMA. Dari ke 30 responden yang ada, 71\% menyatakan perlu dilakukan pengembangan instrument kinerja karena masih sdikit pengembangan instrument kinerja. I9\% responden menyatakan kurang perlu karena penilaian kinerja sudah ada peda perangkat bahan ajar yang dimiliki setiap guru fisika. Sepuluh persen menyatakan tidak perlu karena masih banyak pengembangan yang lain yang lebih penting. Hal tersebut dapat di lihat pada grafik berikut :

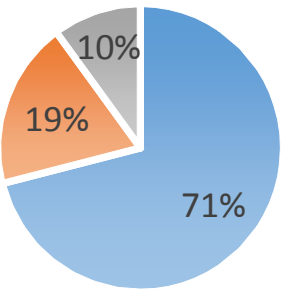

\section{- Perlu Karena Instrumen Penilaian kinerja masih sedikit dikembangkan dalam kegiatan praktikum fisika. \\ - Kurang Perlu karena penilaian kinerja sudah ada pada perangkat bahan ajar yang dimiliki setiap guru Fisika \\ - Tidak Perlu karena masih banyak pengembangan yang lain yang lebih penting}

Gambar I. Analis Kebutuhan

Dari grafik tersebut peneliti melakukan penelitian Pengembangan Instrumen Penilaian Kinerja Berbasis saintifik pada materi pengukuran.

\section{Metode Penelitian}

Metode penelitian yang digunakan adalah metode penelitian dan pengembangan (Research and Development) yakni metode pengembangan yang digunakan adalah metode Borg dan Gall Dengan tahapan studi literature (Research and information collecting), perencanaan (Planning), Pengembangan produk awal (Develop preliminary form of product), Uji coba lapangan skala terbatas (Preliminary field testing), revisi produk (Main product revision),

Uji Coba Skala utama (Main field testing), Penyempurnaan hasil uji coba skala utama (Operational product revision). Uji validasi produk (Operational field testing), melakukan revisi akhir (Final product revision) dan Penyebarluasan produk yang dikembangkan (Dissemination and implementation). Gambar 2 berikut adalah tahapan penelitian menurut [I2].

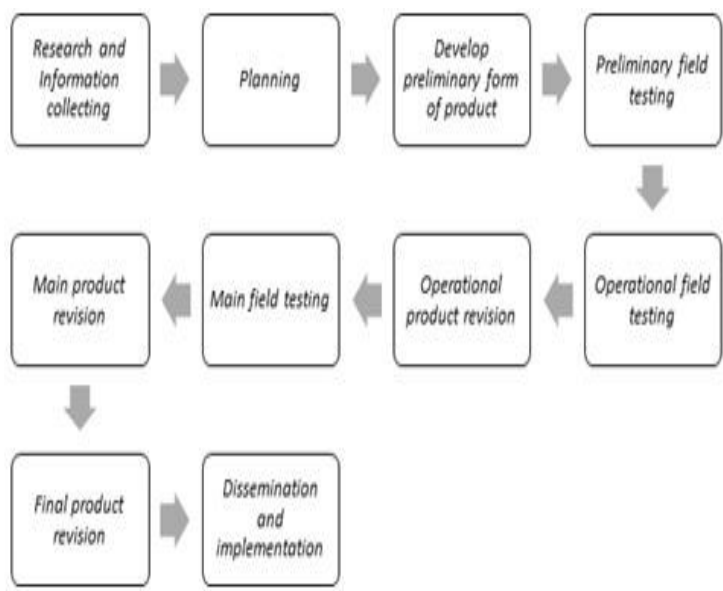

Gambar 2. Tahapan Penelitian 


\section{Research and information collection (penelitian dan pengumpulan data)}

Pada tahapan ini peneliti melakukan analisis kebutuhan. Pengumpulan informasi ini dilakukan dengan menyebarkan angket kepada 30 guru SMA dan studi literatur mengenai kebermanfaatan penggunaan penilaian kinerja dalam mengukur tingkat kompetensi keterampilan peserta didik.

\section{Planning (Perencanaan):}

Instrumen penilaian yang dihasilkan dalam penelitian ini disusun dengan terlebih dahulu menetapkan kompetensi yang akan dinilai. Kompetensi dasar yang akan digunakan dalam penelitian ini adalah Kompetensi Dasar 4.I yaitu merencanakan dan melaksanakan percobaan pengukuran Kompetensi ini kemudian disesuaikan dengan pendekatan pembelajaran yang digunakan yaitu pendekatan saintifik. Tahap berikutnya adalah menentukan pedoman penskoran instrumen yang akan dikembangkan yaitu daftar skala (scale ratter) dengan skala yang digunakan adalah skala I -4 . Setelah bentuk instrumen ditetapkan, berikutnya adalah melakukan penyesuaian materi ajar yaitu materi pengukuran dengan percobaan pengukuran panjang dan pengukuran massa benda.

\section{Develop preliminary form of product (pengembangan draf produk awal)}

Setelah informasi-informasi yang didapatkan dirasa cukup untuk menjadi dasar pengembangan instrumen, maka tahap selanjutnya adalah pengembangan produk. Langkah awal dalam mengembangkan instrumen penilaian ini adalah membuat kisi-kisi instrumen dimana terdapat dimensi penilaian yang akan digunakan dan indikator penilaian. penilaian yang akan digunakan adalah dimensi penilaian kinerja berbasis saintifik, karena pendekatan ini mewakili seluruh aktivitas pembelajaran yang telah ditetapkan. Pendekatan saintifik yang digunakan (I) Mengamati, (2) Menanya, (3) Menalar, (4) mencoba/Melakukan eksperimen, (5) Melakukan Jejaring (Menerapkan konsep dan rumus).

Setelah dibuat indikator untuk masing-masing tahapan pembelajaran dalam kegiatan praktikum, maka langkah selanjutnya adalah membuat butir penilaian. Adapun jumlah butir penilaian yang dibuat sebanyak 48 Butir pada materi pengukuran penilaian ini dibuat berdasarkan indikator yang telah dirumuskan dalam kisi-kisi. Selanjutnya ditentukanlah rubrik penilain. Rubrik yang disusun terdiri atas 4 kriteria, yaitu 4 dengan kriteria sangat baik, 3: Baik, 2: Kurang baik dan I kriteria sangat kurang baik.
Setelah membuat desain awal berupa penentuan dimensi, indikator serta rubrik penilaiannya maka dilakukan validasi desain produk. Validasi produk dilakukan dengan metode telaah pakar atau ahli dan guru. Ahli atau pakar yang memvalidasi terdiri dari 3 dosen dan 2 orang guru. Dimana 2 dosen yang ahli pada bidang fisika, I dosen ahli dalam bidang bahasa dan 2 orang guru fisika. Validasi ahli ini bertujuan agar desain produk dapat diuji cobakan

\section{Preliminary field testing (Uji coba lapangan awal)}

Pada tahapan ini dilakukan uji coba lapangan awal dalam skala terbatas. dengan melibatkan subjek sebanyak IO orang peserta didik. Langkah ini merupakan uji produk secara terbatas, yaitu melakukan uji lapangan awal terhadap desain produk, yang bersifat terbatas, baik substansi desain maupun pihak-pihak yang terlibat. $\mathrm{Uji}_{\mathrm{j}}$ lapangan awal dilakukan secara berulang-ulang sehingga diperoleh desain yang layak, baik substansi maupun metodologi. Selama uji coba diadakan pengamatan, wawancara dan pengedaran angket. Pengumpulan data dengan kuesioner dan observasi yang selanjutnya dianalisis.

\section{Main Product revision (Revisi produk hasil Uji coba)}

Tahapan ini merupakan perbaikan model atau desain berdasarakan uji lapangan terbatas. Penyempurnaan produk awal akan dilakukan setelah dilakukan uji coba lapangan secara terbatas.

\section{Main field testing (Uji produk secara lebih luas)}

Pada tahapan ini peneliti melakukan uji coba lapangan skala besar. Dengan melibatkan 33 peserta didik dalam proses pengambilan data. Kelas dipilih yang mewakili karakteristik peserta didik dalam sekolah tersebut. Pemilihan kelas dilakukan secara acak dengan kriteria semua peserta didik dalam kelas tersebut telah mempelajari materi atau topik yang akan diujikan menggunakan instrument penilaian kineja ini. Uji coba lapangan ini dilakukan untuk memastikan bahwa instrument yang digunakan sudah layak dan baik serta memiliki tingkat validitas dan reliabilitas yang baik.

\section{Operational product revision (Revisis hasil uji lapangan lebih luas)}

Pada tahapan ini peneliti melakukan penyempurnaan produk yang sudah diuji coba lapangan skala besar. Kegiatan ini dilakukan untuk memantapkan hasil produk yang dikembangkan dalam hal ini instrument penilaian kinerja berbasis saintifik pada materi pengukuran. Setelah 
Pengembangan Instrumen penilaian kinerja peserta didik berbasis pendekatan saintifik pada praktikum pengukuran kelas X SMA

melakukan uji coba lapangan, maka akan didapatkan data yang kemudian digunakan untuk mendapatkan tingkat validitas dan reliabilitas dari instrumen yang dikembangkan. Revisi dilakukan untuk memastikan bahwa instrument yang digunakan sudah valid dan reliable.

\section{Operational field testing (Uji Kelayakan)}

Pada tahapan ini peneliti melakukan uji efektivitas baik desain produk, calon pengguna produk dan hasil uji lapangan pada model desain yang siap diterapkan.

\section{Final Product revision (Revisi hasil uji kelayakan)}

Pada tahapan ini penyempurnaan produk final. Penyempurnaan produk akhir dipandang perlu untuk lebih akuratnya produk yang dikembangkan. Pada tahap ini sudah didapatkan produk yang efektif.

\section{Desiminasi and implementasion (Desiminasi dan Implementasi Produk Akhir)}

Pada tahapan ini hasil pengembangan produk dipublikasikan melalui forum-forum ilmiah atau pun media massa. Sedangkan untuk pendistribusian produk harus dilakukan setelah melalui quality control.

\section{Hasil dan Pembahasan}

Pengembangan instrumen penilaian kinerja pendekatan saintifik dimulai dengan studi pendahuluan dimana peneliti melakukan analisis kebutuhan di beberapa sekolah yaitu menyebar angket ke 20 guru SMA untuk mengetahui apakah penilaian kinerja sangat diperlukan dalam kegiatan pembelajaran khususnya dalam kegiatan praktikum. Hasil yang didapat adalah penilaian kinerja sangat diperlukan.

Selain itu analisis juga dilakukan pada pendekatan yang digunakan yaitu pendekatan saintifik. Pendekatan tersebut dipilih karena sesuai dengan tujuan pemerintah dan karakteristik pembelajaran Fisika yang cocok dengan pendekatan saintifik dalam kegiatan pembelajaran. Tahapan pendekatan saintifik menjadi acuan penyusunan butir penilaian kinerja yang dapat dilakukan oleh guru dalam melihat peserta didik saat kegiatan praktikum. Selain hal tersebut materi yang akan dipilih pada instrumen yang dikembangkan, yaitu materi pengukuran. Materi tersebut dipilih karena dianggap mudah serta alat dan bahan mudah diperoleh di lingkungan sekitar.

Tahap berikutnya yaitu melakukan uji validasi oleh ahli. Lebih lanjut [I3] menyatakan validitas dapat didefinisikan seperti keseluruhan dari evaluasi. Hasil validasi oleh ahli terhadap instrumen penilaian kinerja dapat dilihat pada tabel berikut:
Tabel I. Hasil penilaian kualitas instrumen penilaian oleh Para Ahli

\begin{tabular}{ccccc}
\hline & Validator & \multicolumn{3}{c}{ Nilai tiap Aspek } \\
\cline { 3 - 5 } No & Expert & $\begin{array}{c}\text { Konstruksi } \\
\text { Instrumen }\end{array}$ & Materi & Bahasa \\
\hline I & Expert I & 80 & 80 & 81 \\
2 & Expert 2 & 83 & 87 & 89 \\
3 & Expert 3 & 75 & 80 & 85 \\
4 & Expert 4 & 90 & 89 & 87 \\
5 & Expert 5 & 85 & 85 & 85 \\
\hline
\end{tabular}

Berikut adalah hasil rata rata validasi expert.

Tabel 2. Tabel Rata-rata hasil penilaian instrument kinerja oleh validator expert.

\begin{tabular}{clcl}
\hline No & \multicolumn{1}{c}{ Aspek } & Nilai & Predikat \\
\hline I & Konstruksi Instrumen & 82.6 & Sangat Baik \\
2 & Materi & 84.2 & Sangat Baik \\
3 & Bahasa & 85.4 & Sangat Baik \\
& Jumlah & $\mathbf{8 4 . 0 6}$ & Sangat Baik \\
\hline
\end{tabular}

Berdasarkan tabel di atas bahwa penilaian instrument penilaian kinerja memiliki kriteria sangat baik. Kesimpulan tersebut diambil berdasarkan tabel acuan dalam menentukan kriteria penskoran menurut sugiono sebagai berikut :

Tabel 3. Kriteria penskoran

\begin{tabular}{cc}
\hline Nilai & Predikat \\
\hline$>80$ & Sangat Baik \\
$75-79$ & Baik \\
$60-74$ & Kurang \\
$<59$ & Sangat Kurang
\end{tabular}

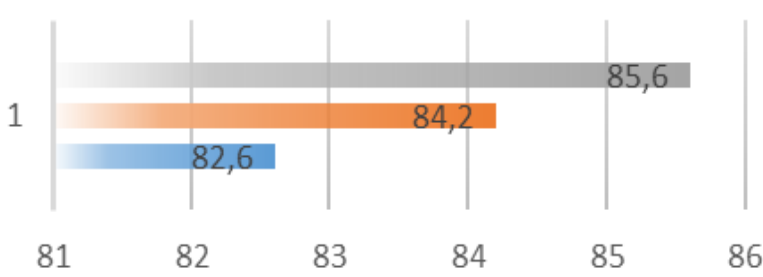

n bahasa = materi \ Konstruksi butir Instrumen

Grafik 3. Grafik Hasil Validasi Expert Instrumen Penilaian Kinerja Materi Pengukuran

Dengan memperhatikan tabel dan grafik hasil penilaian kualitas instrument penilaian kinerja oleh expert dapat dikatakan bahwa kualitas instrumen penilaian yang dilihat dari aspek bahasa, materi dan konstruksi butir instrumen, memiliki rata-rata kualitas yang sangat baik.

Setelah melakukan penilaian, didapatkan masukan dari para ahli expert. Masukan ini diberikan untuk penyempurnaan instrument penilaian kinerja yang dikembangkan. Masukan ini dijadikan acuan untuk 
Pengembangan Instrumen penilaian kinerja peserta didik berbasis pendekatan saintifik pada praktikum pengukuran kelas X SMA

memperbaiki instrumen yang dikembangkan. Pada tabel 4 adalah beberapa masukan dari pada ahli

Tabel 4. Hasil saran dan masukan para ahli

\begin{tabular}{ccl}
\hline No & $\begin{array}{c}\text { Validator } \\
\text { Expert }\end{array}$ & \multicolumn{1}{c}{ Input } \\
\hline I & Expert I & $\begin{array}{l}\text { Gunakan Kalimat dengan tanda huruf } \\
\text { besar dan kecil yang jelas sesuai EYD, } \\
\text { penggunaan bahasa sudah cukup baik. } \\
\text { Tambahkan prosedur kerja yang jelas } \\
\text { sehingga peserta didik tidak banyak } \\
\text { betanya mengenai proses kegiatan dalam } \\
\text { kegiatan praktikum.. } \\
\text { Tahapan dalam butir instrument sudah } \\
\text { bagus, akan tetapi lebih dipersingkat dan } \\
\text { diperjelas saja } \\
\text { Butir instrument sudah cukup baik, } \\
\text { Extuk meteri pengukuran sebaiknya } \\
\text { ditambahkan pada materi pengukuran } \\
\text { volume agar lebih lengkap instrument } \\
\text { pengukurannya } \\
\text { Expert 4 } \\
\text { Tingkat kesulitan proses lebih } \\
\text { diperdalam }\end{array}$ \\
\hline
\end{tabular}

\section{Hasil Uji Coba}

Setelah instrumen diujikan pada peserta didik kelas $\mathrm{X}$ SMAN 73 Jakarta dengan jumlah 33 peserta didik. Analisis lebih lanjut akan dilakukan untuk menguji validitas dan menghitung reliabilitas dengan Product moment menurut [I4] yaitu :

$$
r=\frac{\sum x y-\frac{\left(\sum x\right)\left(\sum y\right)}{n}}{\sqrt{\left(\sum x^{2}-\frac{\left(\sum x\right)^{2}}{n}\right)\left(\sum y^{2}-\frac{\left(\sum y\right)^{2}}{n}\right)}}
$$

Keterangan:

$r_{x y}=$ koefisien korelasi antara variabel $\mathrm{X}$ dan $\mathrm{Y}$, dua variabel yang dikorelasikan

$n=$ Jumlah Responden

$x \quad=$ Skor butir yang dicari validitasnya

Dari 57 butir penilaian yang diujicobakan ke peserta didik, diperoleh 48 butir penilaian kinerja yang valid dan 9 butir penilaian yang tidak valid. Butir penilaian dinyatakan valid untuk nilai rhitung $>\mathrm{r}_{\text {tabel }}$ dan dinyatakan tidak valid untuk rhitung $<$ rabel dengan taraf signifikansi $5 \%$. Setelah mendapatkan informasi terkait tingkat kevalidan instrument penilaian kinerja peserta didik dengan pendekatan saintifik pada materi pengukuran, selanjutnya dihitung nilai reliabilitasnya dengan Alfa crobach.

$$
r_{11}=\left(\frac{k}{k-1}\right)\left(1-\frac{\sum S I^{2}}{S T^{2}}\right)
$$

Keterangan:

$$
\begin{array}{ll}
r_{11} & =\text { Reliabilitas Instrumen } \\
\sum S I^{2} & =\text { Jumlah Varian skor dari setiap butir } \\
k & =\text { Banyaknya butir } \\
S T^{2} & =\text { Varian total }
\end{array}
$$

Dari hasil perhitungan nilai reliabilitas dari instrument penilaian kinerja ini sebesar 0,896 dengan derajat kebebasan (dk) $3 \mathrm{I}$ sehingga $\mathrm{r}_{\text {tabel }}$ sebesar 0,334. Berdasarkan aturan statistik deskriptif instrumen dikatakan reliabel apabila rhitung $>0,602$ dengan taraf signifikansi 5\%.

Menurut [I5], berikut adalah tabel kriteria tingkat reliabilitas instrument

Tabel 5. Kriteria Tingkat Reliabilitas Instrument

\begin{tabular}{ccl}
\hline No & \multicolumn{1}{c}{ Interval } & \multicolumn{1}{c}{ Kriteria } \\
\hline I & $<0,200$ & Sangat rendah \\
2 & $0,200-0,399$ & Rendah \\
3 & $0,400-0,599$ & Cukup \\
4 & $0,600-0,799$ & Tinggi \\
5 & $0,800-1,000$ & Sangat tinggi \\
\hline
\end{tabular}

Dengan demikian butir penilaian ada dalam instrumen penilaian kinerja dengan pendekatan saintifik yang dikembangkan peneliti dinyatakan valid dengan tingkat reliabilitas instrumen dalam kriteria Sangat Tinggi.

Tahap selanjutnya adalah melakukan evaluasi. Pada tahap ini diberikan perlakuan pada butir yang tidak valid dan perlakuan yang diberikan yaitu butir tersebut tidak dimasukkan kedalam instrument penilaian kinerja peserta didik karena dikhawatirkan akan mengurangi kualitas instrumen. Sehingga semua butir-butir penilaian yang sudah dinyatakan layak dan valid dapat dilihat pada tabel berikut:

Tabel 6. Butir penilaian yang layak dan valid

\begin{tabular}{cl}
\hline No & \multicolumn{1}{c}{ Butir Penilaian } \\
\hline I & $\begin{array}{l}\text { Mengamati bahan yang akan di ukur pada } \\
\text { pengukuran panjang benda }\end{array}$ \\
2 & $\begin{array}{l}\text { Mengamati panjang bahan yang akan diukur apakah } \\
\text { terdapat bentuk yang tidak simetri pada bahan } \\
\text { tersebut. }\end{array}$ \\
3 & $\begin{array}{l}\text { Mengamati alat ukur apakah masih berfungsi dengan } \\
\text { baik / tidak. }\end{array}$ \\
4 & $\begin{array}{l}\text { Mengamati besaran fisis dengan posisi mata tegak } \\
\text { lurus terhadap titik pengukuran untuk mengurangi }\end{array}$ \\
5 & $\begin{array}{l}\text { kesalahan paralaks mistar. } \\
\text { lurus terhadap titik pengukuran pada Jangka Sorong }\end{array}$ \\
6 & $\begin{array}{l}\text { Mengamati besaran fisis dengan memperhatikan } \\
\text { ketepatan rahang tetap dan rahang sorong }\end{array}$ \\
7 & $\begin{array}{l}\text { Mengamati besaran fisis dengan memperhatikan } \\
\text { ketepatan skala utama dan skala nonius pada proses }\end{array}$ \\
8 & $\begin{array}{l}\text { pengukuran } \\
\text { Mengamati besaran fisis kedua skala yang berhimpit }\end{array}$ \\
\hline
\end{tabular}


Pengembangan Instrumen penilaian kinerja peserta didik berbasis pendekatan saintifik pada praktikum pengukuran kelas X SMA

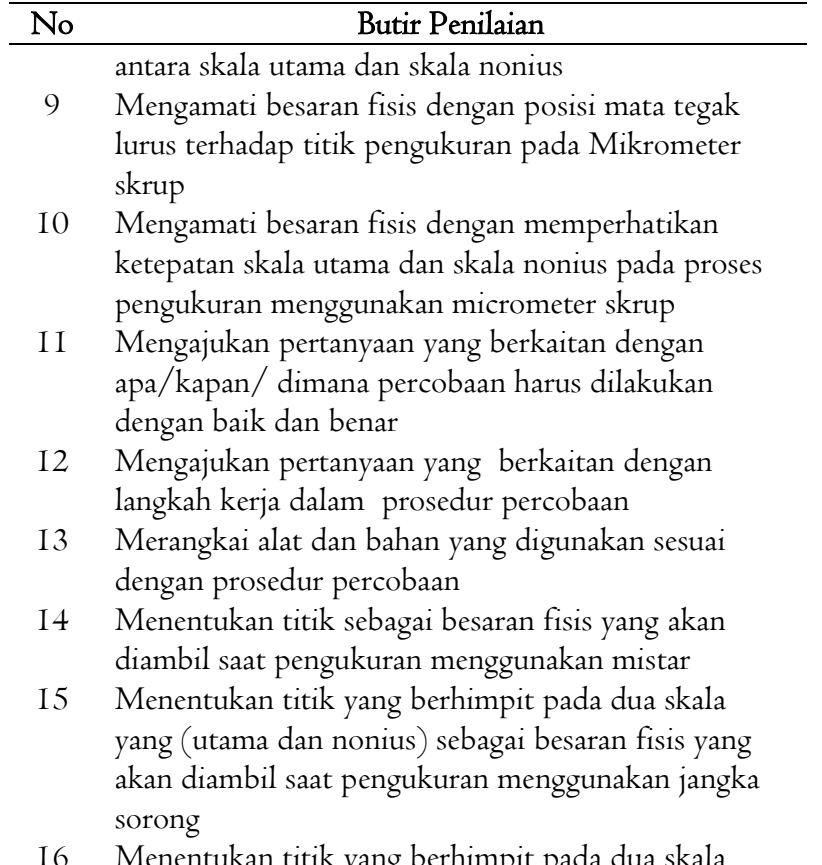

I6 Menentukan titik yang berhimpit pada dua skala yang (utama dan nonius) sebagai besaran fisis yang akan diambil saat pengukuran menggunakan micrometer skrup

I7 Menentukan besaran fisis dengan mengulang percobaan pada pengukuran dengan mistar, jangka sorong dan micrometer skrup

I8 Mengidentifikasikan nilai besaran fisis yang didapatkan dengan prosentase nilai ketidakpastian dalam pengukuran

I9 Menyajikan data hasil percobaan dalam bentuk tabel

20 Menyajikan data hasil percobaan dalam bentuk Grafik

2I Menggunakan bahasa Indonesia yang baik dan benar dalam penyusunan laporan

22 Menyusun laporan secara sistematis, logis, dan rasional

23 Menyampaikan hasil percobaan menggunakan bahasa yang mudah dipahami

24 Mengamati bahan yang akan di ukur pada pengukuran massa benda

25 Mengamati alat ukur apakah masih berfungsi dengan baik / tidak.

26 Mengamati besaran fisis dengan posisi mata tegak lurus terhadap titik pengukuran pada pengukuran menggunakan Neraca Ohauss

27 Mengamati besaran fisis dengan tepat saat terjadi kesetimbangan antara bahan yang digunakan dengan neraca Ohauss

28 Mengamati besaran fisis dengan posisi mata tegak lurus terhadap titik pengukuran pada pengukuran menggunakan Neraca Pegas

29 Mengamati besaran fisis dengan tepat saat terjadi kesetimbangan antara bahan yang digunakan dengan neraca Pegas

30 Mengamati besaran fisis sesuai angka yang keluar pada Neraca Digital

3I Mengamati besaran fisis dengan memperhatikan ketepatan skala pada setiap masing masing Neraca yang digunakan dalam mengukur massa benda.

\begin{tabular}{|c|c|}
\hline No & Butir Penilaian \\
\hline 32 & $\begin{array}{l}\text { Mengamati Nilai yang tertera pada neraca lengan } \\
\text { pada Neraca Ohauss }\end{array}$ \\
\hline 33 & Mengamati Nilai yang tertera pada neraca pegas. \\
\hline 34 & $\begin{array}{l}\text { Mengamati Nilai yang tertera pada display sesuai } \\
\text { skala satuan neraca tersebut. }\end{array}$ \\
\hline 35 & $\begin{array}{l}\text { Mengajukan pertanyaan yang berkaitan dengan } \\
\text { apa/kapan/ dimana percobaan harus dilakukan } \\
\text { dengan baik dan benar }\end{array}$ \\
\hline 36 & $\begin{array}{l}\text { Mengajukan pertanyaan yang berkaitan dengan } \\
\text { langkah kerja dalam prosedur percobaan }\end{array}$ \\
\hline 37 & $\begin{array}{l}\text { Mengajukan pertanyan yang berkaitan dengan } \\
\text { bagaimana percobaan dilakukan dengan baik dan } \\
\text { benar }\end{array}$ \\
\hline 38 & $\begin{array}{l}\text { Merangkai alat dan bahan yang digunakan sesuai } \\
\text { dengan prosedur percobaan }\end{array}$ \\
\hline 39 & Merapikan Alat dan bahan setelah selesai kegiatan \\
\hline 40 & $\begin{array}{l}\text { Menentukan nilai sebagai besaran fisis yang akan } \\
\text { diambil saat pengukuran Neraca ohauss }\end{array}$ \\
\hline $4 \mathrm{I}$ & $\begin{array}{l}\text { Menentukan Nilai sebagai besaran fisis yang akan } \\
\text { diambil saat pengukuran dengan neraca pegas }\end{array}$ \\
\hline 42 & $\begin{array}{l}\text { Menentukan Nilai dari display sebagai besaran fisis } \\
\text { yang akan diambil saat pengukuran dengan neraca } \\
\text { digital }\end{array}$ \\
\hline 43 & $\begin{array}{l}\text { Menentukan besaran fisis dengan mengulang } \\
\text { percobaan pada pengukuran massa benda dengan } \\
\text { menggunakan Neraca Ohauss, Neraca Pegas maupun } \\
\text { Neraca Digital }\end{array}$ \\
\hline 44 & $\begin{array}{l}\text { Mengidentifikasikan nilai besaran fisis yang } \\
\text { didapatkan dengan prosentase nilai ketidakpastian } \\
\text { dalam pengukuran }\end{array}$ \\
\hline 45 & Menyajikan data hasil percobaan dalam bentuk tabel \\
\hline 46 & $\begin{array}{l}\text { Menyajikan data hasil percobaan dalam bentuk } \\
\text { Grafik }\end{array}$ \\
\hline 47 & $\begin{array}{l}\text { Menggunakan bahasa Indonesia yang baik dan benar } \\
\text { dalam penyusunan laporan }\end{array}$ \\
\hline 48 & $\begin{array}{l}\text { Menyusun laporan secara sistematis, logis, dan } \\
\text { rasional }\end{array}$ \\
\hline
\end{tabular}

\section{Kegiatan Praktikum dan seminar}

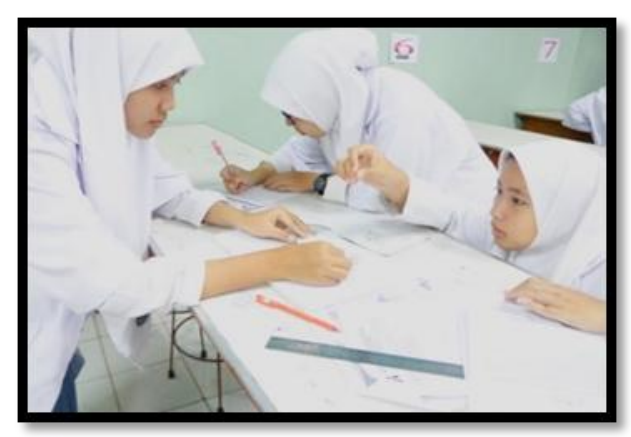

Grafik 4. Siswa sedang melakukan praktik pengukuran panjang menggunakan penggaris 


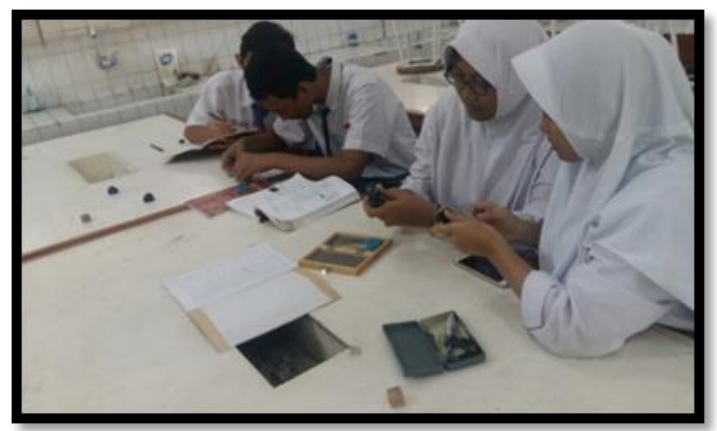

Grafik 5. Siswa sedang melakukan praktik pengukuran ketebalan benda menggunakan mikrometer skrup

\section{Kesimpulan}

Berdasarkan hasil penelitian dan pengembangan diperoleh kesimpulan sebagai berikut:

I. Instrumen penilaian kinerja dengan pendekatan saintifik pada praktikum pengukuran memiliki karakterisitik sederhana, efisien dan mudah digunakan.

2. Persentase instrumen kinerja pendekatan saintifik pada materi pengukuran pada aspek konstruksi instrumen sebesar 82.6, aspek kebahasaan sebesar 85.4 dan materi produk 84.2 dengan masing-masing aspek memiliki kriteria sangat baik

3. Faktor pendukung pada proses pengembangan instrumen penilaian kinerja yaitu respon baik dari guru untuk membantu uji coba lapangan awal. Sedangkan faktor kendalanya yaitu sulitnya mencari sekolah untuk melakukan uji coba lapangan awal.

Saran akan pengembangan instrumen penilaian kinerja sejenis yaitu:

I. Penelitian ini hanya dilakukan sampai tahap revisi hasil uji coba, perlu dilakukan pengembangan lebih lanjut terhadap instrumen penilaian kinerja praktikum ini ke tahap penelitian dan pengembangan selanjutnya, agar produk nantinya dapat digunakan dalam proses pembelajaran fisika di sekolah.

2. Perlu adanya pengembangan instrumen penilaian kinerja dengan pendekatan saintifik pada praktikum yang mudah digunakan oleh guru untuk materi yang lain.

\section{Kepustakaan}

[I] Dewi, M. V. (2016). Rancangan tes dan evaluasi fisika yang informatif dan komunikatif pada materi kinematika gerak lurus. Jurnal Penelitian dan Pengembangan pendidikan fisika, 2, 8I88.

[2] Sudjana, N. (2009). Penilaian Hasil proses belajar mengajar. Bandung. PT Rosda Karya.

[3] Hathcoat, J. D. (2012). Generalizability of Student Writing across Multiple Tasks: A Challenge for Authentic Assessment. Research and Practice in Assessment, 7: 16-28.

[4] Hammond, L. D. (2010). Beyond Basic Skills: The Role of Performance Assess-ment in Achieving 2Ist Century Standards of Learning. Scope, Stanford University.
Pengembangan Instrumen penilaian kinerja peserta didik berbasis pendekatan saintifik pada praktikum pengukuran kelas X SMA

[5] E Quellmaz and Schank, P. (2000). Performance Assessment Link in Science. Jurnal Practical Assessment, Reaseach \& Evaluation, 6-I0.

[6] Mamara. (2008). Asessment Performance. Marmara University.

[7] Serevina, V. (2016). Peningkatan Hasil belajar siswa pada materi dinamika gerak partikel dengan menerapkan model pembelajaran project based learning. Jurnal Pendidikan Fisika.

[8] Sience, G. ((t.t)). Performance Assessment In The Classroom. Newyork: Glencoe Mc Graw-hill.

[9] Streacher, B. (2010). Performance Assessment in An Era Of Standars Based Educational Accountablility. Standord CA : Stanford University, Stanford Center for Opportunity Policy in Education.

[I0] Stiggins, R. J. (1994). Student Centered Classroom Assesment. New York: Merrill.

[II] A. N. Hidayah, Pengembangan Penilaian Unjuk Kerja Berbasis Pembelajaran Inkuiri pada Materi Fisika SMP/MTs Pokok Bahasan Suhu dan Pemuaian, Pendidikan Fisika UIN Sunan Kalijaga, Yogyakarta, 2013.

[12] Borg W.G, G. P. (I989). Education Research. New York: Pearson Education.

[13] Micmillan, J. H. (2008). Asessment Esential For Standar. California: Corwin Press.

[I4] Sugiyono. (2012). Metode Penelitian. Yogyakarta: Andi Offset.

[15] Arikunto, S. (2012). Prosedur Penelitian. Jakarta: PT Bumi Aksara. 